\title{
THE INFLUENCE OF RED FRUIT (PANDANUS CONOIDEUS LAM.) OIL ON GLUTATHIONE PEROXIDASE LEVEL AT MAXIMUM PHYSICAL ACTIVITY
}

\author{
FAJAR APOLLO SINAGA ${ }^{1 *}$, NORA SUSANTI ${ }^{2}$ \\ ${ }^{1}$ Department of Sports Science, Faculty of Sports Sciences, Universitas Negeri Medan, Medan, Indonesia. ${ }^{2}$ Department of Biology, Faculty of \\ Mathematics and Natural Sciences, Universitas Negeri Medan, Medan, Indonesia. Email: sinaga_fajar@yahoo.com
}

Received: 17 January 2018, Revised and Accepted: 14 February 2018

\section{ABSTRACT}

Objectives: This study aims to see the effect of red fruit oil (RFO) on glutathione peroxidase (GPx) level at maximum physical activity.

Methods: This study is an experimental research using the design of randomized control group pretest-posttest. This study was using 24 male mice divided into four groups, the control group was given aquadest, the treatment groups P1, P2, and P3 were given the RFO orally of $0.15 \mathrm{ml} / \mathrm{kg} \mathrm{BW}$, $0.3 \mathrm{ml} / \mathrm{kg} \mathrm{BW}$, and $0.6 \mathrm{ml} / \mathrm{kg} \mathrm{BW}$, respectively, for a month. The level of GPx was checked for all groups at the beginning of study and after the maximum physical activity. The obtained data were then tested statistically using t-test and ANOVA.

Results: The result shows the RFO supplementation during exercise increased the GPx level in P1, P2, and P3 groups with p<0.05, and the higher RFO dosage resulted in higher GPx level at $\mathrm{p}<0.05$.

Conclusion: The conclusion of this study is the RFO could increase the level of GPx at maximum physical activity.

Keywords: Red fruit oil, Maximum physical activity, Glutathione peroxidase.

(c) 2018 The Authors. Published by Innovare Academic Sciences Pvt Ltd. This is an open access article under the CC BY license (http://creativecommons. org/licenses/by/4. 0/) DOI: http://dx.doi.org/10.22159/ajpcr.2018.v11s1.26579

\section{INTRODUCTION}

Heavy physical activities can cause the oxidative stress which result in the increasing free radicals production [1,2]. In the oxidative stress condition, free radicals can oxidize lipid in the cell membrane and thus interrupt the cell membrane organization [3]. Malondialdehyde (MDA) is one of the oxidized species of the membrane lipid that can be produced by maximal physical activities or by high intensity endurance exercises. The level of MDA can be used as a general indicator for free radical level and indirectly pointed the oxidant capacity $[4,5]$.

Researchers showed that the maximum activity can cause the lowering level of endogenous antioxidants, namely, superoxide dismutase, catalase (CAT), glutathione peroxidase (GPx), and glutathione-Stransferase on gastrocnemius muscle [6]. Bulduk et al. reported the high level of MDA and the lowering level of endogenous antioxidants, CAT, and GPx in volleyball athletes after $20 \mathrm{~min}$ of shuttle run [7].

Antioxidant and anti-free radicals mechanism is naturally occur in human body. Free radicals will be neutralized through elaborated system made of enzyme and non-enzyme antioxidants [2,8]. Some researchers reported supplementation of natural or synthetic antioxidants are required for the neutralization of free radicals formed during heavy physical activities [9-12].

Red fruit oil (RFO) (Pandanus conoideus Lam.) is one of the natural resources found in Papua Island and known for its high antioxidant contents (beta-carotene, tocopherol, and unsaturated fatty acids) $[13,14]$. As an antioxidant, the RFO is believed to prevent chronic diseases such as cardiovascular diseases, atherosclerosis, and cancer. In addition, the Papuan believe that this plant can be used to enhance the stamina, but this later property is yet to be proven scientifically.

The result of research conducted by Sinaga stated that RFO can increase the erythrocyte, hematocrit, and hemoglobin level and decrease the leukocyte level in rats during maximal activity. In that research, it is also found that RFO can decrease the MDA level and enhance the rats' stamina during maximal activity [15]. This result is particularly interesting and therefore need further study to discover the effect of RFO on human GPx level at maximal physical activity.

The aim of this study is to find antioxidant compound which has the ability to prevent the formation and decrease the level of free radicals formed during physical activity and therefore enhance the athlete performance and health.

The result of this research is expected to contribute to the body of knowledge, especially as the basic for further research in developing natural medicine for athlete health. The results can be applied during training program and competitions for athlete.

\section{METHODS}

The study was conducted for 6 weeks in Animal Laboratory Unit in Mathematics and Natural Science Faculty of Medan State University. The GPx level was examined in Laboratorium Terpadu (Research Center Lab) in Medical Faculty of North Sumatera University.

This study used 24 healthy male rats. The rats were divided into four groups randomly consisted of six rats in each group. The control group (P0) was given $2 \mathrm{~mL}$ water, the treatment groups (P2, P3, and P4) were given RFO $0.15,0.3$, and $0.6 \mathrm{~mL}$, respectively, per day using gavage spuit. The rats were trained to swim for a month, $15 \mathrm{~min} /$ day in the $1^{\text {st }}$ week, $20 \mathrm{~min} /$ day in the $2^{\text {nd }}$ week, $25 \mathrm{~min} /$ day in the $3^{\text {rd }}$ week, and $30 \mathrm{~min} /$ day in the $4^{\text {th }}$ week. After 30 days, the rats were forced to perform maximal activity by putting the rats in water with no exit. The GPx level was then measured.

\section{RESULTS}

The GPx level prior and after treatment is presented in Table 1.

The GPx level before and after treatment in each group was subject to Shapiro-Wilk normality test and Levene's homogeneity test. Both tests result showed that the data were normal and homogeneous $(p>0.05)$, and therefore, one-way ANOVA and t-paired test were used for parametric test. 
The one-way ANOVA test on GPx level before treatment gave the $\mathrm{F}$ value of 0.555 and $p=0.651$. This result showed that the average Gpx level was not significantly different within and among groups. While the test on GPx level after treatment gave the $\mathrm{F}$ value of 28181.122 and $\mathrm{p}=0.000$ which mean that there is statistically significant difference in the GPx level among groups $(\mathrm{p}<0.05)$.

The t-paired test result showed that the GPx level was lowering in the control group (P0), while in contrast, it was significantly increasing in the treatment groups of P1, P2, and P3 ( $p<0.05$ ) (Fig. 1).

\section{DISCUSSION}

The pre-treatment GPx level average in control group was $35.97 \pm 0.40 \quad(\mathrm{U} / \mathrm{gHb})$, in $\mathrm{P} 1$ group (RFO $0.15 \mathrm{~mL} /$ day) was $36.01 \pm 0.72(\mathrm{U} / \mathrm{gHb}$ ), P2 group (RFO $0.3 \mathrm{~mL} /$ day) was $36.26 \pm 0.53$ (U/gHb), and P3 group (RFO $0.6 \mathrm{~mL} /$ day) was $36.33 \pm 0.62(\mathrm{U} / \mathrm{gHb}$ ). One-way ANOVA test showed that the GPx level pre-treatment among four different groups is not significantly different ( $p>0.05$ ). After treatment, the average of GPx in control group was $30.37 \pm 0.42$, in P1 group was 65.96 \pm 0.56 , in P2 group was $100.26 \pm 0.79$, and in P3 group was $126.69 \pm 0.59$. Statistics analysis showed that there is statistically significant difference among all four GPx average level $(\mathrm{p}<0.05)$.

In normal condition, free radicals were formed slowly and neutralized by naturally occurring antioxidants. In the case, where the free radicals were formed massively which can be caused by heavy training, the level of free radicals will overcome the level of naturally occurring antioxidant in the body and thus were not be neutralized. This later condition can lead to the damage of cellular membrane, muscles, bones, and other tissues [16]. The lowering level of GPx after maximum physical activity can lead to physical stress. Recovering time is needed to maintain the relax body condition after training activity [17]. The oxygen consumption during heavy training can rise up to 20 times higher or even more than normal oxygen consumption. In stress condition, the muscle fiber consumes oxygen more than it does in normal condition. This extreme oxygen consumption can rise the free radicals production in mitochondria which will lead to high GPx usage and lower the GPx

Table 1: The average of GPx level prior and after RFO supplementation at maximal physical activity

\begin{tabular}{llllllll}
\hline Level & Treatment & P0 & P1 & P2 & P3 & F & p \\
\hline GPx & Before & 35.97 & 36.01 & 36.26 & 36.33 & 0.555 & 0.651 \\
& After & 30.37 & 65.96 & 100.26 & 126.69 & 28181.122 & 0.000 \\
t dependent & 0.000 & 0.000 & 0.000 & 0.000 & & \\
\hline
\end{tabular}

GPx: Glutathione peroxidase, RFO: Red fruit oil

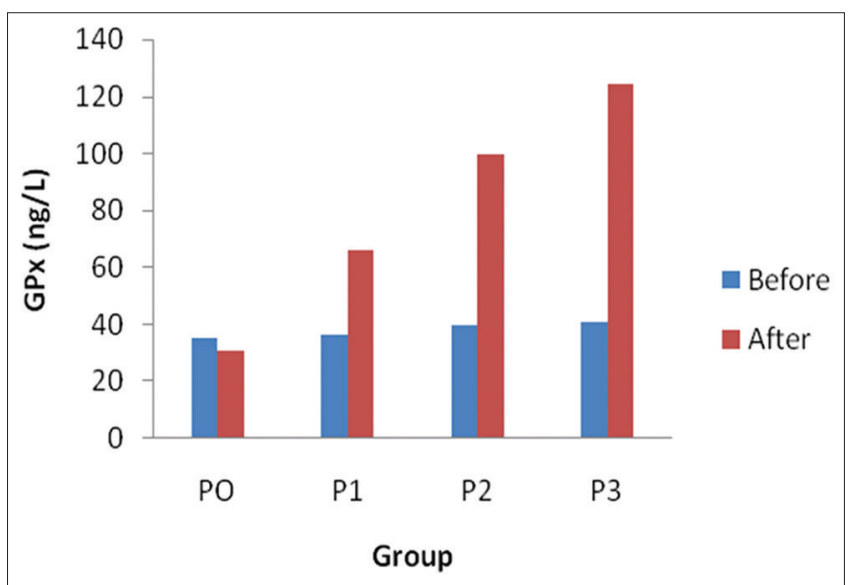

Fig. 1: The glutathione peroxidase level in control and treatment groups before and after red fruit oil supplementation at maximal activity level. In the discontraction muscles, the oxygen level is low and ischemic can occur. To overcome all these unwanted conditions, the antioxidant supplementation is needed [16].

In this study, the supplementation of RFO is found to increase the GPx level. The increasing GPx level was due to the high antioxidant content in RFO such as carotenoids (11.500 ppm), $\beta$-carotene (694.80 ppm), tocopherols (11.200 ppm), and $\alpha$-tocopherol (495.50 ppm) [14]

As one of the natural sources of antioxidant, the antioxidant activity of RFO was studied. Rohman et al. reported in vitro study showed that the RFO exhibited antioxidant activity with IC50 of $451.51 \mu \mathrm{g} / \mathrm{ml}$ [18]. In vivo study, RFO with dosage of $0.15,0.3$, and $0.6 \mathrm{mg} / \mathrm{kg} \mathrm{BW}$ exhibited the ability to lower the blood MDA level $[15,19]$. MDA is one of the peroxidized lipids and the level of MDA can be used as the indicator of free radicals level and oxidant capacity $[4,5,15]$.

The result of this research is in line with the research conducted by Sandhiutami et al. which studied the level of tocopherol after RFO supplementation on male Wistar rats at maximal activity. They found that the level of tocopherol was increasing as the dosage of RFO is risen [19]. Armiyanti et al. reported the lowering level of reactive oxygen intermediate (ROI) on endothelial cell exposed to malaria patient blood serum and normal neutrophil cell after RFO supplementation with concentration of $2.8 \%, 5.7 \%$, and $11.3 \%$. Higher concentration of RFO decreases ROI level [20].

\section{CONCLUSION}

RFO supplementation during exercise program can increase the level of GPx at maximal physical activity.

\section{ACKNOWLEDGMENTS}

The authors thank the Directorate for Higher Education, the National Education Ministry of Republic Indonesia for Research Grant of Hibah Fundamental for financial support.

\section{REFERENCES}

1. Daniel RM, Stelian S, Dragomir C. The effect of acute physical exercise on the antioxidant status of the skeletal and cardiac muscle in the Wistar rat. Roman Biotechnol Lett 2010;15:56-61.

2. Urso ML, Clarkson PM. Oxidative stress, exercise, and antioxidant supplementation. Toxicology 2003;189:41-54A

3. Evans WJ. Vitamin E, vitamin C, and exercise. Am J Clin Nutr 2000;72:647S-52S

4. Wang L, Zhang HL, Zhou YJ, Ma R, Lv JQ, Li XL, et al. The decapeptide CMS001 enhances swimming endurance in mice. Peptides 2008;29:1176-82.

5. Lyle N, Gomes A, Sur T, Munshi S, Paul S, Chatterjee S, et al. The role of antioxidant properties of Nardostachys jatamansi in alleviation of the symptoms of the chronic fatigue syndrome. Behav Brain Res 2009;202:285-90.

6. Thirumalai T, Viviyan TS, Elumalai EK, David E. Intense and exhaustive exercise induce oxidative stress in skeletal muscle. Asian Pac J Trop Dis 2011;1:63-6.

7. Bulduk EO, Ergene N, Baltaci AK, Gumuş H. Plasma antioxidant responses and oxidative stress following a 20 meter shuttle run test in female volleyball players. Int J Hum Sci 2011;8:510-26.

8. Christopher PI, Wenke JC, Nofal T, Armstrong RB. Adaptation to lenghthening contraction-induced injury in mouse muscle. J Appl Physiol 2004;97:1067-76.

9. Ostojic SM, Stojanovic MD, Djordjevic B, Jourkesh M, Vasiljevic N. The Effect of a 4-week coffeberry suplementation on antioxidant status, endurance, and anaerobic performance in college athletes. Res Sports Med 2008;16:281-94.

10. Gupta C, Gupta PH, Singh B. Effect of vitamin supplementation on exercise induced oxidative stress in trained elite Indian cyclists. Am J Biomed Sci 2009;1:166-70.

11. Bentley DJ, Dank S, Coupland R, Midgley A, Spence I. Acute antioksidant suplementation improves endurance performance in trained athletes. Res Sports Med 2012;20:1-12.

12. Kalpana K, Kusuma DL, Lal PR, Khanna GL. Effect of spirulina on 
antioxidant status and exercise-induced oxidative stress of Indian athletes in comparison to a commersial antioxidant. Asia J Exerc Sports Sci 2012;9;36-48.

13. Budi IM. Red Fruit. Jakarta: Penebar Swadaya; 2005.

14. Alamsyah AN. Combination of the Disease Conqueror: $\mathrm{VCO}+\mathrm{Red}$ Fruit. Jakarta: Agromedia Pustaka; 2005. p. 2-45.

15. Sinaga FA. The Effect of Red Fruit Oil on Rat's Malondialdehide at Maximal Physical Avtivity. Proceeding International Conference of ASEAN Council of Physical Education and Sports (ACPES); 2015. p. $379-85$.

16. Cooper K. Healthy Without Medicine: Four ways of Antioxidant Revolution that Change Your Life. $1^{\text {st }}$ ed. Bandung: Kaifa; 2001.

17. Judge S, Jang YM, Smith A, Hagen T, Leeuwenburgh C. Age-associated increases in oxidative stress and antioxidant enzyme activities in cardiac interfibrillar mitochondria: Implications for the mitochondrial theory of aging. FASEB J 2005;19:419-21.

18. Rohman A, Riyanto S, Yuniarti N, Saputra WR, Utami R, Mulatsih W. Antioxidant activity, total phenolic, and total flavonoid of extracts and fractions of red fruit (Pandanus conoideus Lam). Int Food Res J 2010a; 17:97-106.

19. Sandhiutami NM, Ngatijan, Kristin E. Determination of tocopherol content from Buah Merah (Pandanus conodaius Lam.) fruit by in vitro and in vivo method on mouse given maximum physical activity. The Journal of Indonesian Medical Plant. 2012. 5:1 p. 45-52

20. Armiyanti Y, Fitri LE, Widjajanto E. The effect of red fruit oil (Pandanus Conoideus) on oxidative stress of endothelial cells exposed to malaria falciparum patient serum and healthy donor neutrophil. J Kedokt Brawijaya 2007;23:1-8 